\title{
Interactivity in Educational Apps for Young children: A Multimodal Analysis
}

\author{
Alexandra H. Blitz-Raith \\ MA \&MS, Charles Sturt University, Australia, alexandra.blitzraith@live.vu.edu.au \\ Jianxin Liu \\ PhD, Charles Sturt University, Australia, rliu@csu.edu.au
}

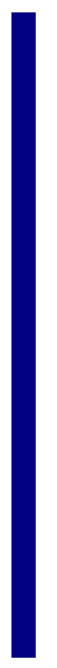

\begin{abstract}
Interactivity is an important indicator of an educational app's reception. Since most educational apps are multimodal, it justifies a methodological initiative to understand meaningful involvement of multimodality in enacting and even amplifying interactivity in an educational app. Yet research so far has largely concentrated on algorithm construct and user feedback rather than on multimodal interactions, especially from a social semiotics perspective. Drawing from social semiotics approaches, this article proposes a multimodal analytic framework to examine three layers of mode in engendering interaction; namely, multiplicity, function, and relationship. Using the analytic framework in an analysis of The Farm Adventure for Kids, a popular educational app for pre-school children, we found that still images are dominant proportionally and are central in the interactive process. We also found that tapping still images of animals on screen is the main action, with other screen actions deliberately excluded. Such findings suggest that aligning children's cognitive and physical capabilities to the use of mode become the primary consideration in educational app design and that consistent attendance to this alignment in mobilizing modes significantly affect an educational app's interactivity, and consequently its reception by young children.
\end{abstract}

Keywords: appification, mode, multimodality, interaction, social semiotics, text

\section{INTRODUCTION}

Interactivity influences educational apps' content, function, relationship, and emotion. As Churchill $(2011,2012)$ elucidates, interactivity affects an educational app's usability and user reception. For instance, how do learners interact with the content and education and how do learners interact with one another? For young children, this is especially pertinent as learning mostly occurs through immersive interactions such as play and experiencing rather than through formal instructions (Hirsch et al., 2015). It is no doubt that unraveling various dimensions of interactivity in educational apps is critical for

Citation: Blitz-Raith, A. H., \& Liu, J. (2017). Interactivity in Educational Apps for Young children: A Multimodal Analysis. International Journal of Instruction, 10(4), 237-254. https://doi.org/10.12973/iji.2017.10414a 
determining their relevance to young children's learning. Since most of educational apps in Apple Store, Google Play, Windows Store and other mobile spaces are multimodal involving modes other than the written text such as sounds, images, and animations, it justifies a methodological initiative to understand meaningful inclusion of multimodality in engendering interactivity in an educational app. A survey of the current literature as summarized in the section that follows further indicates that research has largely concentrated on algorithm construct and user feedback; attention to interactivity is either anecdotal or non-existent in respect of mode coordination, especially from a social semiotics perspective.

This article is an attempt to address this lack. In what follows, we will first overview the main trends and frameworks of educational app design and evaluation to identify promises and challenges. We will discuss why interactivity and multimodality should be a central concern for educational app development and evaluation from a social semiotic perspective. We will then propose an analytic framework to unpack multimodality in educational apps and follow it up with a single app analysis to demonstrate the framework's pertinence. In the last section, we will discuss the features that have emerged from the analysis in line with the analytic framework, the selected educational app, and the key theoretical perspectives to unveil how interactivity is enacted. Because educational apps have been widely adopted in formal and informal learning spaces, we consider the development of the kind of analytic frameworks as timely and important in optimizing apps educational functions.

\section{Review of the Literature}

Apps are simply miniature computer programs running on mobile phones, tablets, web browsers and other smart devices (Noble \& Russell, 2013; Roblyer \& Doering, 2013). They are often commanded by various sensory actions on the screen such as clicking or swiping the relevant icon and speaking to an AI (artificial intelligence) assistant such as Apple Siri, Google Assistant, or Windows Cortana. The arrival of cloud space has further spurred the use and design of apps in the last few years, consequently necessitating the evaluation of apps in order to ensure quality. In education where the digital divide is narrowing and where such technologies are used in and outside classrooms by both teachers and students, app evaluation is particularly important (Roblyer \& Doering, 2013). As iPads and other tablets have been introduced to the classroom, the role and selection of apps and app tools have become an important consideration in learning, collaborating and teaching. Churchill (2012) observes that they were effective for as: a) support for learning in various settings due to portability and fit-for-task suitability, b) support for student engagement and quick access to apps that students require for a particular learning task and c) students of all levels can use apps, especially for reinforcement and rote learning of basic concepts (p. 165).

Such examples are numerous in education. Comic Life, for example, is used for designing comics with free templates. Evernote as an organizational cloud allows users to take and share notes of all kinds and automatically syncs them. Free Books has a large collection of classic English books. Annotate PDF allows teachers and students to 
annotate and share PDF files. Both iBooks and iMovie can be used for digital storytelling. The app version of Microsoft Onenote is handy for taking notes and creating word documents (Miller and Doering, 2014). Similarly, many apps such as Dragonbox are used for addressing subject content such as mathematics and science in real time with simulated activities which would not be possible prior to the invention of these mobile technologies. As an extension of the digital landscape, mobile learning creates alternatives beyond the classroom to make education more accessible and inclusive (Banitt et. al, 2008; Hawkins, et al., 2012; Johnson and Marsh, 2014; Kazmer. et al., 2012). Emerging learning environments such as flipped classrooms, and communal, collaborative, customized, and connected learning spaces have intensified the need for "appification" in education. By creating a diverse environment in which a wide variety of apps are used to increase learning opportunities, mobile learning entails many benefits and challenges for learners with varied abilities and preferences (Lai et al., 2013; Maich and Hall, 2016; Noble and Russell, 2013; Pegrum, et al., 2013 Pilgrim et al., 2012; Wellings and Levine, 2009). For instance, many game-based apps have been developed to improve the conventional "drill and skill" function in a playful fashion.

Salas (2013) discusses the economic effects and learning revenue growth of educational apps. He has recommended sites that have comments and reviews about many different types of available educational apps. He has also noted that some of these have been designed and written by teachers and are cost free. The goal of the site recommendations is to aid teachers in their selection of apps that are classroom friendly and can be incorporated actively into curriculum renewal. This highlights the importance of seeking solutions to improve the means and methods in selecting useful educational apps.

The Apple iPad's inclusion in the classroom has created new opportunities for teaching and learning. Murray and Olcese (2011) question whether or not the iPad and its attended apps constitute a set of resources that enable teachers and students to do things that could not otherwise be achievable in an analogue environment. Some of their findings indicate that "the categories offered by Apple are of little use to educators to help them make decisions" (p. 46) and that the applications written to run OS devices "are woefully out of sync" (p. 48) with modern theories of learning skills that students will need in the $21^{\text {st }}$ century. They suggest that more research become undertaken to understand the core principles of how, where, and why people learn in digitizing environments.

Design-based theory reflects the characteristics that make mobile learning environments unique compared with traditional learning environments. The interfaces with existing technology use characteristics that imply design considerations for specific use and purpose. Miller and Doering (2014) consider the following aspects essential in effectively developing meaningful mobile learning experiences:

i. the use of touch screens and gestures,

ii. contents of use (the affordance of learning across space and time),

iii. scope (modularity that interfaces with existing technology), 
iv. data management (the designer needs to identify the type of data the learner will want or need to record and how it will be accessed for use at another time),

v. mode of access (the use of a generic design using HTML.5, CSS3 and JavaScript will help to ensure that learning environment is accessible to all learners),

vi. design scale (the reduction of content clutter and maximization of the application's functionality), and

vii. incentives (rewards for task completion and encouragement to continue using an application)

Churchill (2012) discusses the ongoing study of apps for delivery via the iPad technology and a conceptual model to support learning. His previous studies (Churchill, 2007,2008 ) help to develop two sets of guidelines for the design of conceptual models; namely, presentation design and design for learning uses. Presentation design links the features of design such as multiple screen, visual, color, audio, animation, multimodal features of the app whereas learning uses design implies the use of a conceptual model supports pedagogical learning in a real environment.

Hirsch et al. (2015) in their study on the use of apps for younger children discuss four evidence-based pillars of learning essential for educational app design: active, engaged, meaningful, and socially interactive. They were considered instrumental to creating "attention" or "motivation"; however, motivation is a meaningless term without tapping into these elements. An important area of learning is known as "active minds on" learning "where the learning activities are designed to engage the student and to build and reshape their thinking and understanding as a natural consequence of their experiences and interactions within learning environments" (Hirsch et al., 2015, p.8). The types of "minds on" learning include activities such as interpretation and the ability to translate words to mental images. App designers may use symbols to support active cognition. This may be useful for mathematical and musical apps. It seems that apps' inbuilt interactivity enables the user to explore more information about a subject or to reach a higher level of learning. The belief in the power of design has compelled Hirsch et al. (2016) to conclude that apps that engage these pillars within the context of a learning goal are most likely to be truly educational.

From a social semiotic perspective, however, such a conclusion looks over-optimistic, if not questionable. A social semiotician would consider an educational app essentially a multimodal text that creates and transacts meaning in context (Kress, 2010, 2015, Kress and Van Leeuwin, 2015). As a key player in creating multimodal text, modes are socially and culturally shaped in enabling resource to make meaning. Modes can include but are not limited to, image, writing, layout, speech, and animation. Their typification is often situated in relation to research design and participants. Writing, for instance, is realized by syntax, grammar, lexis, punctuation, font, color and size. Speech is enabled by loudness, pitch and pitch variation, tonal and vocal quality, length and silence. Image utilizes the positioning of elements in a framed space (e.g., size, color, shape, icons, lines, circles); and in the case of animation, the movement of a succession of images. These differences in modes mean that they can be used to do different semiotic work with different resources in different ways. Modes also entail different affordances, 
potentials and constraints in the making of meaning. Burlamqui and Dong (2015, p.308) regard affordance as "cues of the potential uses of an artefact by an agent, in a given environment". In app development, various modes are remixed to make meaning through the affordances of the modal resources. Therefore, meaning is orchestrated through the selection and configuration of modes. In other words, it is the interactivity between the modes and their characteristics that is significant for meaning making.

Interactivity describes the affordance of a medium or the media's potential ability to allow the user to exert an influence on the content (Jensen, 1998). Furthermore, the analysis of interactivity can offer insights into a user's perceived interaction (McMillan, 2009) and the ways in which the users and images respond to meaning making. Educational apps naturally depend on interactivity in order to enable user participation. Links and buttons are not only signs of making meaning, but also sites of action producing. Social semiotics can be used to discuss the relationship between their form, the actions required to activate them, and the effects that can be produced. In this regard, it is imperative to develop a framework that can help unfold interactivity in educational apps.

\section{METHOD}

This study adopts multimodal discourse analysis (MDA) as its research method. MDA, as an emerging member of discourse analysis (DA) family, focuses on understanding how non-discursive modes such as image, color, sound, and movement are employed as semiotic resource in creating meanings (Baldry \& Thibault, 2006; Kress, 2010). In what follows, we will describe three aspects of this MDA study; namely, 1) the criteria for selecting a suitable educational app as the data, 2) the process that prepares the selected educational app for the study, and 3) the analytic framework for uncovering interactivity among the modes involved in the educational app.

\section{Data collection}

The data for this study was collected from a popular children's educational app, Farm Adventures for Kids. According to Baldry and Thibault (2006), text selection in MDA should take into account the nature of text and the context around the kind of text. As such, to inquire into the applicability of the above-discussed MDA framework, we developed four criteria in selecting the educational apps; namely, a) the selected educational app should work on multiple mobile operating systems, b) it should relate to a curriculum, c) it should be affordable, and d) it should be popular. The app we have finally chosen for the analysis, Farm Adventure for Kids, fulfils these selection criteria. The app is aimed at young children who may not have the opportunity to visit farms or see farm animals. It is available as a free app in both Apple Store and Android Play Store. It has a four star (out of five) rating, with more than one million downloads and over 700 in-store customer reviews. Since the contents of the app include learning skills universally stipulated in early years curriculum such as learning the alphabet, spelling and recognition skills, and simple math such as counting, it may be used as a complementary learning tool or space in the school classroom. As Figure 1 below illustrates, the app visualizes what a farm looks like and what kinds of animals and foods 
are raised on an animated journey. Its What's New section in Apple Store and Android Play Store indicates that its developer believes that it would help create mentally and physically adventures that lead to active learning and personalized discovery.

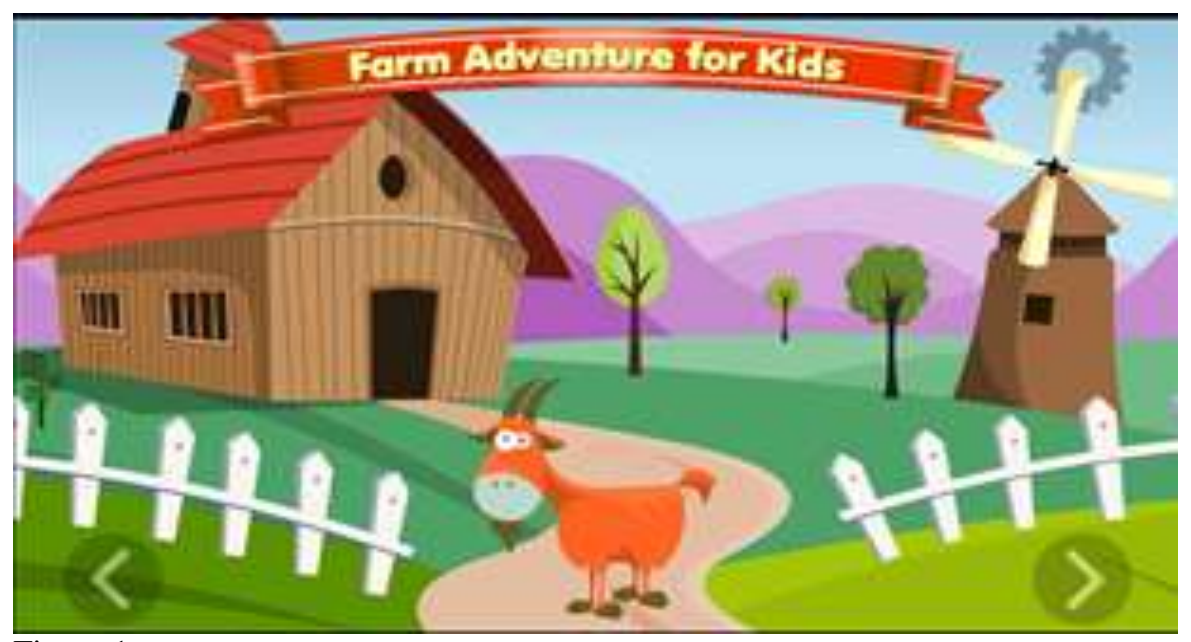

Figure 1

A Screenshot of Farm Adventure for Kids

\section{Data transcription}

Data collected from the selected educational app was processed and labelled in line with the app's progress from level one to level ten. Each level of the apps was further annotated by Content, Learning Activity, and Stage (see Table 1). This annotation would prepare the data systematically to accommodate the nuanced analysis of modes. Table 1 summarizes the 10 levels of activities in the app. The table indicates that levels one and two are designed as learning activities and that levels three, four and five involve games that reinforce what has been learnt. The first two levels involve basic learning skills for the young learners. They cover the contents that are taught at school and introduce more complex concepts as the young learner's skillset improves. Level six uses named and brightly colored shapes that can also be dragged and dropped to complete puzzles. Level seven is used for dropping objects, whilst level eight increases the scale of difficulty. Level nine is composed of games and level ten tests what has been learnt from completing the earlier levels. The app uses games for counting, spelling, recognition of color, shapes, and sounds to enrich young learners' understanding. 
Table 1

Contents of Farm Adventures for Kids

\begin{tabular}{|c|c|c|c|}
\hline Level & Content & Learning Activity & Stage \\
\hline 1 & $\begin{array}{l}\text { Alphabet } \\
\text { animals, } \\
\text { numbers, fruits, } \\
\text { vegetables }\end{array}$ & $\begin{array}{l}\text { The characters appear on the screen moving from right } \\
\text { to left after tapping } \\
\text { The name of the animal and the sound it makes is heard } \\
\text { as are the other animated artefacts }\end{array}$ & $\begin{array}{l}\text { Introducing } \\
\text { skills }\end{array}$ \\
\hline 2 & Colors & The names of different colors are learnt & \\
\hline 3 & Sort Games & $\begin{array}{l}\text { Vegetables are sorted and placed in their basket. } \\
\text { The names of the different vegetables are learnt }\end{array}$ & \multirow{3}{*}{$\begin{array}{l}\text { Consolidating } \\
\text { skills }\end{array}$} \\
\hline 4 & $\begin{array}{l}\text { Labyrinth } \\
\text { Games }\end{array}$ & $\begin{array}{l}\text { Eggs that will be used to form words are collected } \\
\text { The spelling of the names of the animals is learnt }\end{array}$ & \\
\hline 5 & Jump Games & $\begin{array}{l}\text { Fruits, vegetables, letters of the alphabet and numbers } \\
\text { are collected } \\
\text { This is a learning and dexterity testing game. }\end{array}$ & \\
\hline 6 & Match Games & $\begin{array}{l}\text { Shapes in the boxes are arranged to form a new figure. } \\
\text { The names of shapes are learnt }\end{array}$ & \multirow{3}{*}{$\begin{array}{l}\text { Complicating } \\
\text { skills }\end{array}$} \\
\hline 7 & Drop & $\begin{array}{l}\text { The names of fruits and vegetables are learnt } \\
\text { This reinforces what has been learnt }\end{array}$ & \\
\hline 8 & Shaped Fence & A game for learning numbers and shapes & \\
\hline 9 & Play games & $\begin{array}{l}\text { Connecting colors to the animals } \\
\text { These are dexterity games; }\end{array}$ & \multirow{2}{*}{$\begin{array}{l}\text { Advancing } \\
\text { skills }\end{array}$} \\
\hline 10 & Quizzes & $\begin{array}{l}\text { Knowledge and skills that have been learnt are tested. } \\
\text { This is used to reinforce what has been learnt }\end{array}$ & \\
\hline
\end{tabular}

\section{Data analysis}

To analyze the selected educational app, we have developed a MDA framework as described in the following. We will explore its application and possible extension through the analysis of this educational app. We have come to a realization that developing an educational app-specific analytic framework be more useful than a blanket adoption of an existing model. We envision the analytic framework with the following three attributes. First, it should be able to describe the modes involved and their occurrence. Second, it should be able to describe the functions and roles of the modes involved. Third, it should be able to describe the relationship between the modes involved. Inclusion of these attributes is anticipated to provide a semiotic delineation of the connections between multimodality. It is also anticipated that the analysis may help generate tangible categories and scales that can be exploited in further quantitative investigations. We focus our attention mainly on five primary types of mode, namely, 1) still image, 2) animated image, 3) movement, 4) sound, and 5) written text. To ensure the analysis's coherence and feasibility, other modes and modalities such as color, typography, and shape are excluded from the present study, considering mode complexity, as well as the unsettled theoretical debate around modes, modality, and medium (e.g., Bezemer \& Jewitt, 2010). 


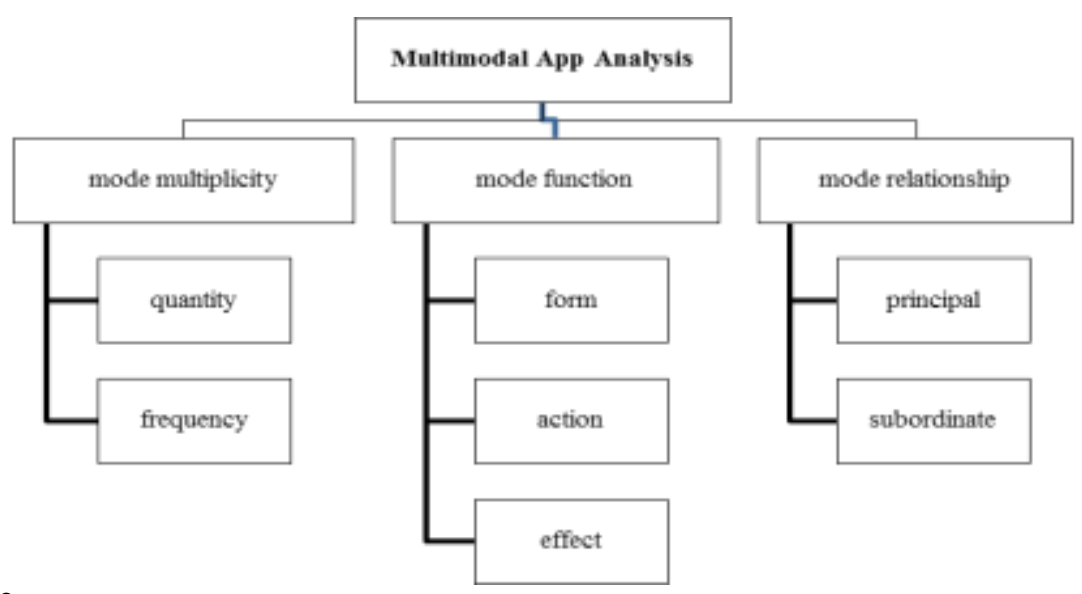

Figure 2

A MDA framework for educational apps analysis

As Figure 2 illustrates, the proposed multimodal analytic framework comprises three layers: mode multiplicity, mode function, and mode relationship. The first layer of the framework, mode multiplicity, examines occurrence of the involved in creating an educational apps. This decision is inspired by Norris's (2004) view that when all the modes that participate in the modal interaction are interconnected, multimodal interaction can be described by examining attributes such as modal density, intensity, complexity, and weight. Norris's categorizations are certainly useful in generating interpretations; yet, they are of little use to hands-on analysis of the mode presence in educational apps, as conceptual terms rather than as tangible variables or factors. Mistaking conceptual terms for variables in this respect may result in fatal data processing errors, especially when an analysis is applied to developing large-scale databases or is adapted as computational models. In lieu of Norris' model, mode multiplicity in this framework focuses on a) the number of modes; i.e., how many modes are used, and b) the frequency of modes; i.e., how often does a mode recur. Both are attributes that can be numerated to represent Norris' conceptual terms such as modal density, complexity, intensity, and weight. It should be pointed out there that other factors such as distance and cluster are equally useful but are temporarily excluded in consideration of this article's purpose.

The second layer of the framework, mode function, identifies what a mode can do in enabling an educational app's interactivity. In his analysis of websites, Adami (2013) adapted the three metafunctions of Systemic Functional Grammar (Halliday, 1994; Kress, 1996; Martin, 1993), namely, ideational, interpersonal, and textual, to account for the interactive meaning potentials of website as digital text. Adami's adaptation pertains to the present study on educational apps in that both websites and apps are semiotic texts that instantiate discoursal attributes inclusive of interactivity from a social semiotics point of view. Interactions between iPad users and iPad apps are comparable to those between web surfers and websites. In this sense, the attributes developed by Adami 
(2013) can be refined to accommodate mode functions required in the present analytic framework. They include: (a) a meaningful form; i.e., what does a mode look like, (b) an action; i.e., what does a mode do, and (c) an effect; i.e., what is a mode's impact. In other words, the function is realized by the form that a mode takes, by the action that is needed to produce an effect, and by the effect is that is produced from this combination of mode functions.

The third layer of the framework, mode relationship, examines how modes are related to one another in an educational app. From an orthodox semiotic perspective on multimodality (Burlamqui and Dong, 2014; Kress, 2010, 2015), the concept of anchorage must be evoked in locating the modes that anchor the meaning of all participating modes. Adhering to this perspective seems reasonable but in practice is not productive or illuminating in that 1) the relationships among the modes around the anchor can hardly be usefully delineated against a reliable framework, and 2) it may be interpreted as patriarchal when a particular mode is predetermined to dominate the entire meaning making process. Text analysts on the other hand offer a different approach by focusing on how meaning is (in) coherently and (in) effectively engendered in a text. Seeing language as a system, several textual linguists (De Beaugrande, 1981; Lemke, 2005; Mann \& Thompson, 1988) have managed to identify rather elaborate textual relations, devices, and principles. While acknowledging their contributions, rather than becoming entangled in the complexity of textual systems, we have decided to focus on identification of modes that make the meaning explicit and of modes that create details or support. We label the former the principal mode and the latter the subordinate mode. We are conscious that other kinds of mode relations such as conditional and concessional are equally important and will return to them in further studies. It should be noted that methodological validity and reliability is not a point of discussion in this exploratory, qualitative study but should be addressed carefully in future corpusoriented larger scale analyses that involve layers of variables.

\section{FINDINGS}

The app's interactivity is explored in the following three levels of multimodal analysis. Conscious of the space, we only present the analysis of the app's first four levels in the tables that follow.

\section{Mode multiplicity}

Table 2 summarizes the first four levels of this analysis. The quantity and frequency of modes are described and numerated. An X is placed to indicate a mode's absence. 
Table 2

Mode multiplicity

\begin{tabular}{|c|c|c|c|}
\hline Level & Mode & Quantity & Frequency (Times) \\
\hline \multirow[t]{5}{*}{1} & Still image & 2 & Tapping on the screen and tapping on an animal \\
\hline & Animated image & 7 & Once per animal \\
\hline & Movement & 7 & Once per animal moving from right to left \\
\hline & Sound & 7 & $\begin{array}{l}\text { Animal noise and narrator clearly says animal name, } \\
\text { background music }\end{array}$ \\
\hline & Written text & 7 & Instructions and name of each animal \\
\hline \multirow[t]{5}{*}{2} & Still image & 1 & Tapping on the screen and tapping on a color \\
\hline & Animated image & 10 & Once per animal \\
\hline & Movement & 7 & Once per color being removed \\
\hline & Sound & 7 & Narrator clearly says colorr name, background music \\
\hline & Written text & $\mathrm{X}$ & $\mathrm{X}$ \\
\hline \multirow[t]{5}{*}{3} & Still image & 2 & Tapping on the screen and tapping on a vegetable \\
\hline & Animated image & 3 & Once per vegetable \\
\hline & Movement & 7 & Once per animal moving from right to left \\
\hline & Sound & 7 & Narrator clearly says vegetable name and background music \\
\hline & Written text & $\mathrm{X}$ & $\mathrm{X}$ \\
\hline \multirow[t]{5}{*}{4} & Still image & 2 & $\begin{array}{l}\text { Tapping on the screen and tapping once for each letter of the } \\
\text { alphabet }\end{array}$ \\
\hline & Animated image & 7 & Once for each letter of the alphabet \\
\hline & Movement & 7 & $\begin{array}{l}\text { Once per animal and once for each letter of the alphabet used } \\
\text { to spell the animal name }\end{array}$ \\
\hline & Sound & 7 & $\begin{array}{l}\text { Narrator clearly says each letter and the name of the animal } \\
\text { and background music }\end{array}$ \\
\hline & Written text & 7 & Name of the animal \\
\hline
\end{tabular}

The analysis shows that each level has at least four modes; namely, the still image, animated image, movement and sound. The primary mode across the four levels are animated image of the screen and animals. Movement is manifested in signs such as the dog wagging its tail and colored blocks falling. Sound appears across the four levels in two forms: a) background music and b) animal sounds. The same background music has been used throughout all levels of the app. Farm animal sounds such as the dog barking or the horse neighing and the narrator are accompanied by enunciation of animal names in words and letters. The written text which appears in levels 1 and 4 adds to the modal complexity and density of the interlinked nodes.

\section{Mode functions}

This part of analysis further examines the functions of the identified modes across the levels of the app. Table 3 summarizes the mode functions presented in the first five levels of the app. 
Table 3

Mode Functions

\begin{tabular}{|c|c|c|c|c|}
\hline Level & Mode & Form & Action & Effect \\
\hline \multirow[t]{3}{*}{1} & $\begin{array}{l}\text { Still } \\
\text { image }\end{array}$ & $\begin{array}{l}\text { Physical action } \\
\text { tapping by index } \\
\text { finger }\end{array}$ & $\begin{array}{l}\text { Animated animals } \\
\text { move from right to } \\
\text { left }\end{array}$ & $\begin{array}{l}\text { Each animal's name appears and is } \\
\text { spoken by narrator. Animal makes a } \\
\text { noised e.g. dog barks }\end{array}$ \\
\hline & $\begin{array}{l}\text { Animated } \\
\text { image }\end{array}$ & $\begin{array}{l}\text { Animated } \\
\text { animals }\end{array}$ & $\begin{array}{l}\text { Animated animals } \\
\text { move left to right }\end{array}$ & $\begin{array}{l}\text { Each animal's name appears and is } \\
\text { spoken by narrator. Animal makes a } \\
\text { noised e.g. dog barks }\end{array}$ \\
\hline & $\begin{array}{l}\text { Still } \\
\text { image }\end{array}$ & Windmill & Appears in frame & Windmill blades slowly move \\
\hline \multirow[t]{2}{*}{2} & $\begin{array}{l}\text { Still } \\
\text { image }\end{array}$ & $\begin{array}{l}\text { Physical action } \\
\text { tapping by index } \\
\text { finger }\end{array}$ & $\begin{array}{l}\text { Colored blocks } \\
\text { appear }\end{array}$ & $\begin{array}{l}\text { Each color is spoken y narrator as they } \\
\text { appear }\end{array}$ \\
\hline & $\begin{array}{l}\text { Still } \\
\text { image }\end{array}$ & Colored shapes & $\begin{array}{l}\text { Colored blocks } \\
\text { appear }\end{array}$ & $\begin{array}{l}\text { Each color is spoken y narrator as they } \\
\text { appear }\end{array}$ \\
\hline \multirow[t]{2}{*}{3} & $\begin{array}{l}\text { Still } \\
\text { image }\end{array}$ & $\begin{array}{l}\text { Physical action } \\
\text { tapping by index } \\
\text { finger }\end{array}$ & $\begin{array}{l}\text { Assorted vegetables } \\
\text { moving right to left } \\
\text { above basket }\end{array}$ & $\begin{array}{l}\text { Each vegetable is named by narrator } \\
\text { and is dropped into a basket if tapped } \\
\text { in time }\end{array}$ \\
\hline & $\begin{array}{l}\text { Still } \\
\text { image }\end{array}$ & $\begin{array}{l}\text { Animated } \\
\text { vegetables }\end{array}$ & $\begin{array}{l}\text { Assorted vegetables } \\
\text { moving right to left } \\
\text { above basket }\end{array}$ & $\begin{array}{l}\text { Each vegetable is named by narrator } \\
\text { and is dropped into a basket if tapped } \\
\text { in time }\end{array}$ \\
\hline \multirow[t]{2}{*}{4} & $\begin{array}{l}\text { Still } \\
\text { image }\end{array}$ & $\begin{array}{l}\text { Physical action } \\
\text { tapping by index } \\
\text { finger }\end{array}$ & $\begin{array}{l}\text { Gathering assorted } \\
\text { letters of the } \\
\text { alphabet }\end{array}$ & $\begin{array}{l}\text { Each letter is named and spoken by the } \\
\text { narrator until the animal's name is } \\
\text { written }\end{array}$ \\
\hline & $\begin{array}{l}\text { Still } \\
\text { image }\end{array}$ & Animated animal & $\begin{array}{l}\text { Gathering assorted } \\
\text { letters of the } \\
\text { alphabet }\end{array}$ & $\begin{array}{l}\text { Each letter is named and spoken by the } \\
\text { narrator until the animal's name is } \\
\text { spelt }\end{array}$ \\
\hline
\end{tabular}

The tables show that the mode in each level is the still image which takes form of a physical action realized by tapping the index finger on the touchscreen. This produces the action of movement of the animated image with the effect that the animal's or object's name appears and is articulated by the narrator when the image is tapped. In level 3 there is additional movement of the fruit/vegetables dropping into a basket after tapping. Level 4 is more complex in that immediately would an animal's name appear in the written text when each letter of the alphabet is spoken

\section{Mode relationships}

This part of analysis examines the relationship among the present modes in the app by identifying which modes are principal and which modes are subordinate, as Table 4 below summarizes. 
Table 4

Mode Relationships

\begin{tabular}{|c|c|c|c|}
\hline \multicolumn{2}{|c|}{ Level Principal mode } & \multirow{2}{*}{$\begin{array}{l}\text { Subordinate mode } \\
\text { Movement }\end{array}$} & \multirow{2}{*}{$\begin{array}{l}\text { Elaboration } \\
\text { Dog running, cat jumping }\end{array}$} \\
\hline 1 & Animated image of animals & & \\
\hline & & Sound & Dog barking, horse neighing \\
\hline & & Written text & $\begin{array}{l}\text { The name of the animal appears and is } \\
\text { clearly spoken }\end{array}$ \\
\hline \multirow[t]{2}{*}{2} & Animated image of color & Movement & Colored shapes move and stack \\
\hline & & Sound & The name of the color is clearly spoken \\
\hline 3 & Animated images of artefacts & Movement & Vegetables moving from right to left \\
\hline \multirow[t]{3}{*}{4} & Animated image of alphabet & Movement & $\begin{array}{l}\text { Each letter jumps and moves to spell } \\
\text { the name of an animal }\end{array}$ \\
\hline & & Sound & $\begin{array}{l}\text { The names of the letters and the animal } \\
\text { appears and is clearly spoken }\end{array}$ \\
\hline & & Written text & $\begin{array}{l}\text { The name of the animal appears and is } \\
\text { clearly spoken }\end{array}$ \\
\hline
\end{tabular}

The principal mode in each level is the animated image and the common subordinate mode is movement. The movement is seen in the animated artefact such as the dog wagging its tail, the vegetables jumping into the basket. Sound is a subordinate mode of levels 1,2 and 4, adding to the complexity of the mode relation typified by the intonation and enunciation by the narrator while the overlay of simple and repetitive background music occurs in all levels. The written text is a subordinate mode of levels 1 and 4. As the levels increase in complexity, more common subordinate modes are visible in every level such as movements and spatial effects, probably to enhance the principal mode.

\section{DISCUSSION}

We discuss in this section several features that have emerged from the analysis in relation to interactivity. First, it appears that that still images play a significant role in creating the app's interactivity. More than 100 still images appear across the five levels and each of the images occurs four times. For example, the farmyard, the farmyard map (layout), the picture of a pointing index finger as instruction to tap the screen and additional tasks at the end of each level. Still images, though not as animated, function not only as background of the app to delineate the farm activities but also to facilitate collaboration among other modes. To some extent, this resonates with Bezemer and Kress' (2008) observation that a visual and verbal depiction of the same thing can be thought of as two different semiotic representations of the same phenomenon to engender a simultaneous semiotic relationship of identity and differentiation. Lemke (2002. p. 3) explains "that it is this essential incommensurability that enables new meanings to be made from combinations of modalities in text". As the meaning-making affordances of image and text differ, they interact synergistically in the construction of meaning for young children. From an evolutionary cognitive perspective (Gazzaniga, 2004; Heyes, 2012), this semiotic saturation of still images also underscores the importance of visual perception in human learning, particularly in creating attention, sustaining motivation, and scaffolding tasks. Knowingly an essential avenue to empowering young children in learning, it has been long neglected due to the dominance 
of written texts and the print as well as the cost in mass production of images. It seems inevitable that effective educational apps development for children have to embrace a renaissance of "the visual" in planning and design.

Further, we noticed that among all the possible actions afforded by smart devices, tapping is the most frequently intended action. Even more interestingly, tapping is usually initiated by a still image of a farm animal and then followed by a typical sound effect and/or movement of the animal. An example of this is the tapping the start screen in level one and animated animals start moving from right to left across the screen. Tapping on the animal produces the spoken name of the animal as well as the sound the animal makes. For example, the name of horse appears as texts and is spoken and then the horse neighs. On the surface, this responds to the design-based approach (Miller and Doering, 2014) which stresses the place of the touchscreen's materiality and affordance in facilitating app-based activities. However, it does not explicate systematically or coherently how tapping as an action bridge the transition from a mode's form to its effects. It is likely that a touchscreen action grammar is in need of development to look into this kind of transition, semiotically. Since educational apps on mobile smart devices are mostly enabled by the touches screen, a delineation of users' common hand movements on the screen is necessary in developing this semiotic grammar; they may include 1) tapping (fast or slow), 2) swiping (left, right, up, or down), and 3) circling (long press or light touch). It is also necessary to examine whether these actions involve just left or right hand or both hands coordination. Whether these screen actions are present and how often they occur are important indicators of an educational app's interactivity.

As Kress and Van Leeuwin (1996, 2006) state, image, color, music, typography and other visual modes are similar to language; in other words, they can simultaneously fulfil and realize broad communicative functions in a similar manner to language in that image and other visual modes have the capacity to form texts. Kress (2003) believes that different logics govern the mode of written language and that of visual image. Written text is governed by the logic of time or temporal sequence whereas visual image is governed by the logic of spatiality, organized arrangements, and simultanicity. In other words, meaning is derived from position in the temporal sequence of written text, whereas meaning is made from the spatial relations or grammar of visual images (Kress \& Van Leeuwin, 1996). Although this claim has been challenged (Prior, 2005), it does offer a useful angle in understanding why image tapping is a designated feature of the chosen app.

Further from there, we noticed that animal images are also central in constructing mode relationship. Still images of the farm animals are the most frequent among the identified principal modes while other modes such as written text and hyperlinks are either nonexistent or subordinate. An affordance point of view (Gibson, 1979) may suggest that animal images engender not only visual imagination but also desires to experience and restructure visual representations. The concept of anchorage crystallizes the kind of image-to-image or image-to-text relationship in which the embedded image functions as a semiotic anchor. Other anchors such as links and buttons enable users to act upon the site, thus obtaining some effects. This aligns closely with the trend that the written text is 
no longer the central mode of representation in learning materials such as textbooks, web-based resources and teacher-produced material (Bezemer and Kress, 2010). Moreover, moving images are found to be increasingly prominent as carriers of meaning. That is another indicator that educational app design should embrace more vigorous multimodal text analysis as such to understand the role of interactivity.

This testifies to a reality that although interactivity is a widely used transdisciplinary term, it is still perceived as under-defined and undertheorized as if it is an elusive concept employed to refer to different phenomena (Adami, 2013; Bucy, 2004; McMillan, 2002; Sundar, 2004). Kress (2003) argues that interactivity is a remix of interpersonality and hypertextuality. Interpersonality has an effect on social power directly whereas hypertextuality has an effect on semiotic power and through that on social power less immediately (Kress, 2003). This remix encompasses mode multiplicity, function, and relationship as described in this article; e.g., images can be combined with other modes and actions while spatial and temporal modal activity adds to the complexity of their inter-semiotic relationship. Even though the kind of mode relationship uncovered in the analysis is singular, it opens up doors to more comprehensive, nuanced examination of inter-semiotic relations afforded by multimodal educational apps.

Most importantly, we noticed from the analysis that consistency seems to serve as a coordinating principle in achieving textual coherence when the app is considered as a text from a social semiotic point of view. For example, throughout the entire app, still images are consistently employed as the dominant mode and tapping as the main action, which may be indicative of the designer's adherence to children's cognitive ability and physical coordination. A simple mode relationship that anchors still images as the principal modes and other modes as subordinate aligns with children's interpersonal development, albeit being overly simplistic. Children's sense of self, their perception of others, and their connections to the beings around them operate in a relatively less complex fashion and should be explicitly addressed in designing this kind of educational apps. Consistency in this regard is paramount in that it ensures a thorough attendance to the overarching context in educational design.

\section{CONCLUSION}

We may well conclude our analytical discussion by highlighting the importance of mode selection, arrangement, and connection in creating an educational app's interactivity and its user reception. We suggest that the key to an app's success may not lie in the profusion of modes but in what modes are included and how they are mobilized and interconnected. Such configurations of modes may not simply be determined by the medium (the device), the ecology (the app system), the modes available, or the technology. Instead, they may be shaped by insider's understanding of young userstheir cognitive ability, their physical ability, and their habitus such as interests and preferences. Apparently, even though the analytic framework employed in the analysis is useful, further adjustment is needed in order to undertake multiple-case or large-scale analysis. For instances, mode functions should spell out various groups of forms, actions, and effects. Various types of subordinate relationship can be further identified 
and examined. It is inevitable that this analytic framework be refined beyond the sole confinement of design on its sociological inquiry voyage of educational apps.

\section{REFERENCES}

Adami, E. (2013). A social semiotic multimodal analysis framework for website interactivity. Mode Working Paper, 1-12.

Banitt, J., Theis, S., \& Van Leeuwe, L. (2013). The effects of technology integration on student engagement: An action research report. Retrieved on the $20^{\text {th }}$ of March 2017 from http://sophia.stkate.edu/cgi/viewcontent.cgi?article=1006\&context=maed.

Baldry, A., \& Thibault, P. J. (2006). Multimodal transcription and text analysis: A multimedia toolkit and coursebook. London: Equinox.

Bezemer, J., \& Jewitt, C. (2010). Multimodal analysis: Key issues. Research methods in linguistics, 181-197.

Bezemer, J., \& Kress, G. (2008). Writing in multimodal texts: A social semiotic account of designs for learning. Written Communication, 25(2), 166-195.

Bucy, E. P. (2004). Interactivity in society: Locating an elusive concept. The Information Society: An International Journal, 20(5), 373-383.

Burlamaqui, L., \& Dong, A. (2015). The use and misuse of the concept of affordance. In J.S. Gero (Ed), Design Computing and Cognition DCC'14 (pp. 295-311). London: Springer.

Churchill, D. (2007). Towards a useful classification of learning objects. Educational Technology Research and Development, 55(5), 479-497.

Churchill, D. (2011). Conceptual model learning objects and design: Recommendations for small screens. Educational Technology \& Society, 14(1), 203-216.

Churchill, D. (2012). Towards recommendations for design of educational apps. Paper presented at the International Conference on Education and e-Learning (EeL). Singapore.

De Beaugrande, R. D. (1982). The story of grammars and the grammar of stories. Journal of Pragmatics, 6(5), 383-422.

Gazzaniga, M. S. (2004). The cognitive neurosciences. Cambridge, Mass: MIT Press.

Gibson, J. J. (1979). The ecological approach to visual perception. London: Houghton Mifflin.

Hawkins, A., Graham, C. R., \& Barbour, M. K. (2012). "Everybody is their own island": Teacher disconnection in a virtual school. International Review of Research in Open and Distance Learning, 13(2), 123-144.

Hirsh-Pasek, K., Zosh, J. M., Golinkoff, R. M., Gray, J. H., Robb, M. B., \& Kaufman, J. D. (2015). Putting education in educational apps. Psychological Science in the Public Interest, 16(1), 3-34.

Heyes, C. D. (2012). New thinking: The evolution of human cognition. Philosophical Transactions of the Royal Society, 367(1599), 2091-2096.

Johnston, N., \& Marsh, S. (2014). Using iBooks and iPad apps to embed information literacy into an EFL foundations course. New Library World, 115 (1/2), 51-60. 
Jensen, J. E. (1998). Interactivity: Tracing a new concept in media and communications studies. Nordicom Review 19(1), 185-204

Kazmer, M., Gibson, A., \& Shannon, K. D. (2013). Perceptions and experiences of elearning among on-campus students.

Kress, G. R. (2003). Literacy in the new media age. London: Routledge.

Kress, G., \& Selander, S. (2012). Multimodal design, learning and cultures of recognition. The Internet and Higher Education, 15(4), 265-268.

Kress, G. (2010). Multimodality. A social semiotic approach to contemporary communication. London: Routledge.

Kress, G. (2015). Semiotic work: Applied linguistics and a social semiotic account of multimodality. AILA Review, 28(1), 49-71.

Kress,,G., \& Van Leeuwen, T. (1996). Reading images: The grammar of visual design. London: Routledge.

Kress, G., \& Van Leeuwen, T. (2001). Multimodal discourse: The modes and media of contemporary communication. London: Arnold.

Kress, G. (2005). Gains and losses: New forms of texts, knowledge, and learning. Computers and composition, 22(1), 5-22.

Lai, K. W. Khaddage, F., \& Knezek, G. (2013). Blending student technology experiences in formal and informal learning. Journal of Computer Assisted Learning, 29(5), 414-425.

Lemke, J. (1995). Textual politics: Discourse and social dynamics. London: Taylor \& Francis.

Lemke, J. (2002). Travels in hypermodality. Visual Communication, 1(3), 299-325.

Maich, K., \& Hall, C. (2016). Implementing iPads in the inclusive classroom setting. Intervention in School and Clinic, 51(3), 145-150.

Mann,W. C., \& Thompson, S. A. (1988). Rhetorical structure theory: Towards a functional theory of text organization. Text-Interdisciplinary Journal for the Study of Discourse, 8(3), 243-281.

McMillan, S. J. (2002). Exploring models of interactivity from multiple research traditions: Users, documents, and systems. In L. Lievrouw \& S. Livingstone (Ed), Handbook Of new media (pp.162-182). London: Sage.

Miller, C., \& Doering, A. (2014). The new landscape of mobile learning: Redesigning education in an app-based world. Hoboken: Taylor and Francis.

Murray, O. T., \& Olcese, N. R. (2011). Teaching and learning with iPads, ready or not? TechTrends, 55(6), 42-48.

Noble, D., \& Russell, A. C. D. (2013). Research on webbed connectivity in a webbased learning environment: Online social work education. Journal of Teaching in Social Work, 33, 496-495

Norris, S. (2004). Analyzing multimodal interaction a methodological framework. New York: Routledge. 
Pegrum, M., Oakley, G., \& Faulkner, R. (2013). Schools going mobile: A study of the adoption of mobile handheld technologies in Western Australian independent schools. Australasian Journal of Educational Technology, 29(1), 66-81.

Pilgrim, J., Bledsoe, C., \& Reily, S. (2012). New technologies in the classroom. Delta Kappa Gamma Bulletin, 78(4), 16-22.

Prior, P. (2005). Moving multimodality beyond the binaries: A response to Gunther Kress' "Gains and Losses". Computers and Composition, 22(1), 23-30.

Roblyer, M. D., \& Doering, A. H. (2013). Integrating educational technology into teaching. Boston: Pearson.

Salas, A. (2013). EDU apps-ology. The Hispanic Outlook in Higher Education, 23, 15-17.

Sundar, S. S. (2004). Theorizing interactivity effects. The Information Society: An International Journal, 20(5), 385-389.

Van Leeuwen, T. (2005). Introducing social semiotics. London: Routledge

Wellings, J., \& Levine, M. H. (2009). The digital promise: Transforming learning with innovative uses of technology. Joan Ganz Cooney Center at Sesame Workshop. Retrieved on the 21th of March 2017 from http://www.intel.com.tr/content/dam/doc/white-paper/education-the-digital-promisetransforming-learning-with-innovative-uses-of-technology-paper.pdf

\section{Turkish Abstract}

\section{Küçük Çocuklar İçin İnteraktif Eğitim Uygulamaları: Bir Çoklu Mod Analizi}

Bu makale sosyal göstergebilim yaklaşımlarından yola çıkılarak, etkileşim yaratmada üç katman modelini incelemek için çokluk, işlev ve ilişki olmak üzere çok modlu bir analitik çerçeve önermektedir; Analitik çerçeve, okul öncesi çocuklar için popüler bir eğitim uygulaması olan The Farm Adventure for Kids'in bir analizinde kullanılarak, hareketsiz görüntülerin oransal olarak egemen olduğu ve interaktif süreçte merkez olduğunu tespit edilmiştir. Ayrıca, hayvanların hareketsiz görüntülerini ekranda izlemenin başlıca eylem olduğu ve diğer ekran işlemlerinin kasıtlı olarak hariç tutulduğunu keşfedilmiştir.

Anahtar Kelimeler: uygulama, mod, çoklu mod, etkileşim, sosyal göstergebilim, metin

\section{French Abstract}

Interactivité dans Apps Éducatifs pour Jeunes enfants: une Analyse Multimodale

En dessinant d'approches de sémiotique sociales, cet article propose un cadre analytique multimodal pour examiner trois couches de mode dans l'engendrement de l'interaction; à savoir, multiplicité, fonction et relation. En utilisant le cadre analytique dans une analyse de l'Aventure Agricole pour des Enfants, un app éducatif populaire pour des enfants d'école maternelle, nous avons constaté que les images fixe sont dominantes proportionnellement et sont centrales dans le processus interactif. Nous avons aussi constaté que le découvrant des images fixe d'animaux sur l'écran est l'action principale, avec d'autres actions d'écran délibérément exclues.

Mots Clés: appification, mode, multimodalité, interaction, sémiotique sociale, texte 


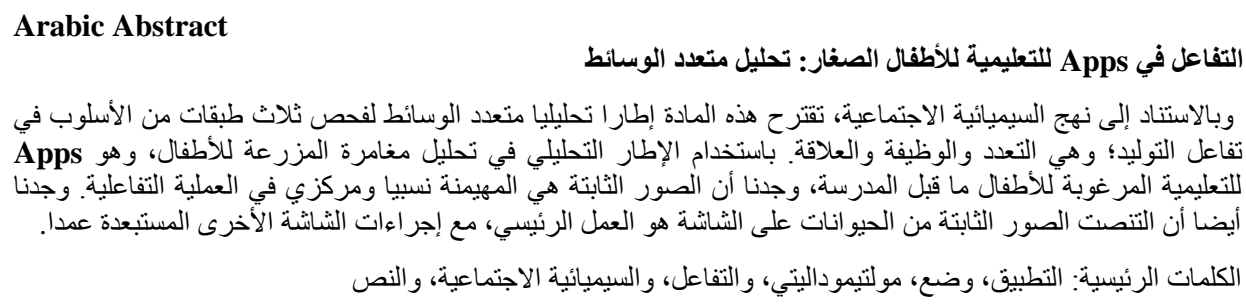

\section{German Abstract}

Interaktivität in Bildungs-Apps für Kleinkinder: Eine multimodale Analyse

Ausgehend von sozialen Semiotik-Ansätzen, schlägt dieser Artikel ein multimodales analytisches Framework vor, um drei Schichten des Modus bei der Erzeugung von Interaktion zu untersuchen; nämlich Multiplizität, Funktion und Beziehung. Mit dem analytischen Rahmen in einer Analyse von The Farm Adventure for Kids, einer beliebten Bildungs-App für Vorschulkinder, fanden wir, dass noch Bilder proportional dominieren und im interaktiven Prozess zentral sind. Wir haben auch festgestellt, dass das Tippen von Bildern von Tieren auf dem Bildschirm ist die wichtigste Aktion, mit anderen Screen-Aktionen bewusst ausgeschlossen.

Schlüsselwörter: angabe, modus, multimodalität, interaktion, soziale semiotik, text

\section{Malaysian Abstract \\ Interaktiviti dalam Aplikasi Pendidikan untuk Kanak-kanak Kecil: Analisis Multimodal}

Menggambar dari pendekatan semiotika sosial, artikel ini mencadangkan rangka kerja analisis multimodal untuk mengkaji tiga lapisan mod dalam interaksi yang mencetuskan; iaitu, kepelbagaian, fungsi, dan hubungan. Menggunakan rangka kerja analisis dalam analisis The Farm Adventure for Kids, aplikasi pendidikan yang popular untuk kanak-kanak prasekolah, kami mendapati imej pegun dominan secara proporsional dan menjadi pusat dalam proses interaktif. Kami juga mendapati bahawa mengetuk gambar binatang di skrin adalah tindakan utama, dengan tindakan skrin lain sengaja dikecualikan.

Kata Kunci: aplikasinya, mod, multimodaliti, interaksi, semiotik sosial, teks

\section{Russian Abstract}

Интерактивность Образовательных Приложений для Детей Младшего Возраста: Мультимодальный Анализ

Основываясь на подходах социальной семиотики, в этой статье предлагается мультимодальная аналитическая структура для изучения трех уровней моделей в процессе формирования взаимодействия; а именно, множественность, функции и взаимосвязь, использование аналитической основы при анализе фермерского приключения для детей, популярное учебное приложение для детей дошкольного возраста, мы обнаружили, что неподвижные изображения доминируют пропорционально и занимают центральную роль в интерактивном процессе. Мы также обнаружили, что нажатие неподвижных изображений животных на экране является основным действием, при этом другие действия экрана сознательно исключены.

Ключевые Слова: приложение, режим, мультимодальность, взаимодействие, социальная семиотика, текст 